\title{
SKETSA DESAIN RUANGAN USAHA MIKRO KONVEKSI DI PASAR KLEWER SURAKARTA
}

\author{
Agung Riyardi \\ Fakultas Ekonomi dan Bisnis \\ Universitas Muhammadiyah Surakarta \\ Agung.Riyardi@ums.ac.id
}

\begin{abstract}
The aim of the public servicing is to draw a simple design of Ar Ridho kiosk at Klewer traditional market, Surakarta city. This simple design is hoped as a basic in designing the kiosk that supports kiosk revenue increasing. The public servicing method used is a stakeholder and contingency approach assistancy method. The stakeholder approach is used in order to gain effectiveness in assistancy, while the contingency approach is used in order to gain more than one simple designs. The result is three pleasant, attractive and informative simple designs. All of simple designs have a similarity in describing a pleasant and attractive kiosk, but different in describing an informative kiosk. The pleasant and attractive kiosk is described by the vastness of kiosk. The first simple design describes an informative kiosk because provides an information computer, the second simple design describes a more informative kiosk because provides an information computer and mirror, and the third simple design describes an informative kiosk because provides an information computer, mirror and dressing room. Consummers respond the simple designs. Some responds suggest improvement into 2 or 3 simple design dimension and cost calculation for each simple design, while other responds suggest to the kiost such as room widening, display grouping and on-line transaction.
\end{abstract}

Kata Kunci: desain, kios, nyaman, menarik, informatif

\section{PENDAHULUAN}

Kios konveksi Ar Ridho adalah salah satu kios di Pasar Klewer Surakarta. Posisi kios adalah di lantai 1 sisi Barat Pasar Klewer Surakarta. Kios Ar Ridho memandang bahwa pengembangan desain kios diharapkan meningkatkan omzet per bulan hingga Rp 20 juta per bulan atau lebih.

Desain kios mampu meningkatkan omzet sebab desain kios meningkatkan produktivitas pekerja kios dan meningkatkan interes dan loyalitas konsumen. Pekerja di kios semakin produktif karena desain kios memberi suasana kerja perdagangan yang kompetitif. Adapun konsumen mengalami peningkatan interest dan loyalitas karena desain kios 'memanjakan' mereka.

Tidak mudah mewujudkan desain kios yang memenuhi harapan tersebut. Perlu dibuat sketsa terlebih dahulu sebab sketsa tersebut dapat menjadi persiapan awal meuuju desain seperti yang diharapkan. Jika sudah ada sketsa, desain mudah diwujudkan.

Kios Ar Ridho menganggap bahwa salah satu peluang yang dapat diraih adalah keragaman konsumen. Mereka adalah 
wisatawan, pejabat, pegawai kantoran, pelaku usaha, penduduk kota Surakarta sekitar pasar Klewer, penduduk kota Surakarta dan penduduk kabupaten/kota sekitarnya yang jauh dari pasar Klewer. Pembelian mereka pun beragam. Ada yang membeli dalam partai besar, jumlah banyak dan ada yang membeli untuk keperluan sendiri dan keluarga. Diperkirakan, meraih keragaman pangsa pasar akan meningkatkan omzet bulanan dari Rp 12.5 juta per bulan menjadi Rp 17,5 juta hingga 20 juta per bulan.

Kadang-kadang terpikir bahwa perkembangan selanjutnya adalah pasar kelas menengah ke atas dan pasar ekspor. Kalau keragaman diraih tentunya pasar menengah ke atas di Surakarta dan pasar ekspor dapat diraih. Peluang di masa mendatang ini semakin mendorong kios Ar Ridho untuk mengembangkan usaha.

Permasalahannya, desain ruangan kios yang ada saat ini, tidak dipersiapkan untuk mengakomodasikan keragaman konsumen. Memang sudah ada berbagai pelanggan yang berdatangan dengan berbagai keragamannya, namun harus diakui bahwa usaha ini tidak disiapkan untuk menangkap peluang tersebut. Ruangan kios didesain sesuai dengan keinginan pemilik, dan kurang mempertimbangkan kebutuhan keragaman konsumen. Inilah kelemahan yang ada.

Persaingan dari sesama kios konveksi di pasar Klewer menjadi ancaman tersendiri. Kios Ar Ridho bukan satu-satunya kios konveksi di pasar Klewer, bukan satusatunya yang ingin meraih interest dari berbagai pangsa pasar dan bukan pula satusatunya yang berpikiran jangka panjang meraih interest dari kalangan menengah ke atas dan pasar ekspor. Kenyataannya di pasar Klewer terdapat 2.075 kios, yang mengindikasikan kemungkinan tidak adanya barriers to exit dan kegagalan usaha, kecuali kalau ada usaha untuk serius meraih interest dari konsumen.

Kekuatan yang dimiliki diharapkan menjadi landasan dalam menguraikan permasalahan yang ada. Jaringan pada akses pengembangan dan kedekatan dengan konsumen menjadi batu loncatan untuk menyelesaikan permasalahan yang ada. Kekuatan ini diharapkan di satu sisi mampu meminimalisir kelemahan dan ancaman dan di sisi lain merubah peluang menjadi kenyataan.

Oleh karena itu, perlu ada terobosan yang menyebabkan dapat meraih peluang keragaman konsumen dan nantinya dapat membantu mewujudkan mimpi meraih pangsa pasar kelas menengah ke atas dan di masa mendatang peluang globalisasi di kancah internasional. Desain ruangan kios adalah terobosan yang dipilih. Ruangan kios akan didesain dalam bentuk nyaman, menarik dan informatif bagi pelanggan yang melakukan pembelian. Nyaman dalam arti kios memberi peluang kepada pelanggan untuk merasa 'at home' ketika melakukan keputusan pembelian, menarik dalam arti kios memberi peluang kepada pelanggan untuk terpenuhi kebutuhan-kebutuhannya dan informatif dalam arti kios memberi peluang kepada pelanggan untuk melakukan keputusan pembelian secara rasional.

Permasalahannya, desain kios seperti itu harus direncanakan dengan baik. Tanpa ada perencanaan yang baik, desain kios yang dihasilkan tidak akan memenuhi harapan untuk meraih keragaman konsumen. Oleh karena itu, perlu suatu sketsa terlebih dahulu sebelum dibuat suatu desain tertentu untuk kios Ar Ridho yang mampu menggambarkan sebagai kios yang nyaman, menarik dan informatif.

Sketsa kios yang nyaman, menarik dan inormatif harus memenuhi tiga kriteria. Pertama, sketsa kios harus menjadi persepsi bersama seluruh stakeholder kios Ar Ridlo. Jika menjadi persepsi bersama, mereka akan 
berpartisipasi dalam penyiapan sketsa, desain dan implementasi selanjutnya. Selanjutnya, mereka sudah memiliki 'persiapan' terhadap atau minimal memahami perlunya terjadi berbagai perubahan. Kedua, sketsa kios harus menyelesaikan permasalahan bisnis yang dihadapi kios Ar Ridlo. Perlu pendalaman yang mampu menyimpulkan bahwa permasalahan dasar terletak pada belum adanya satu sketsa atau lebih bagi disain kios yang nyaman, menarik dan informatif. Ketiga, sketsa kios harus mengakomodasikan interest konsumen. Mereka harus tahu dan menyampaikan pendapat terhadap sketsa kios.

Perumusan masalah dalam pengabdian masyarakat ini adalah

1. Bagaimana mewujudkan kesamaan persepsi di antara stakeholder kios Ar Ridho bagi sketsa kios yang nyaman, menarik dan informatif?

2. Bagaimana mewujudkan sketsa kios Ar Ridho yang nyaman, menarik dan informatif?

3. Bagaimana persepsi konsumen terhdap sketsa kios Ar Ridho yang nyaman, menarik dan informatif?

\section{Keberhasilan dalam Persaingan}

Persaingan harus dilakukan di antara para penjual. Banyaknya pembeli tidak berarti tidak ada persaingan di antara penjual. Bahkan semakin banyak pembeli, semakin bersemangat bersaing. Persaingan merupakan kehidupan para penjual.

Persaingan di antara penjual merupakan suatu yang wajar. Penjual berusaha melebihkan diri dibandingkan penjual lain. Harapan penjual melalui persaingan dengan melebihkan dirinya dari penjual lain adalah memperoleh interest dan loyalitas pembeli.
Tidak mudah bagi penjual untuk melakukan persaingan. Permasalahannya, penjual berhadapan dengan para pembeli yang seperti raja dalam arti berkuasa dalam keputusan pasar. Pembeli misalnya, dapat mengumpulkan informasi pasar sebanyakbanyaknya. Pembeli juga dapat membanding-bandingkan barang dijual untuk menguji tingkat homogenitas produk maupun tingkat stabilitas harga. Apalagi di antara penjual tidak mungkin mengurangi ketajaman persaingan sebagaimana tidak mungkin menambah ketajaman persaingan karena keterbukaan luas pasar. Penjual harus mengeluarkan seluruh kemampuannya dalam persaingan dengan sesama penjual.

Keberhasilan persaingan adalah imbalan yang diperoleh penjual. Kesungguhan dan kerja keras menemui interest dan loyalitas pembeli. Keberhasilan persaingan layak diraih penjual.

Keberhasilan dalam persaingan berwujud keuntungan normal. Hal ini disebabkan penjual bersaing dengan wajar. Mereka tidak mungkin berkolusi dengan sesama penjual. Demikian juga mereka tidak mungkin menekan dan mempengaruhi keputusan pembeli. Keuntungan yang diperoleh penjual adalah keuntungan yang wajar.

Gambar 1 menunjukan keuntungan normal yang diraih penjual. Keuntungan diperoleh karena penjual bersaing dengan penjual lain sedemikian hingga harga relatif stabil pada harga $P$, menjual produk sebanyak Q* karena menyesuaikan dengan biaya tambahan (MC), dan membayar biaya ratarata (AC), yang di dalamnya sudah termasuk biaya oportunitas sebagai keuntungan penjual. Dengan demikian, keuntungan penjual sebagai keberhasilannya dalam persaingan adalah keuntungan normal. 


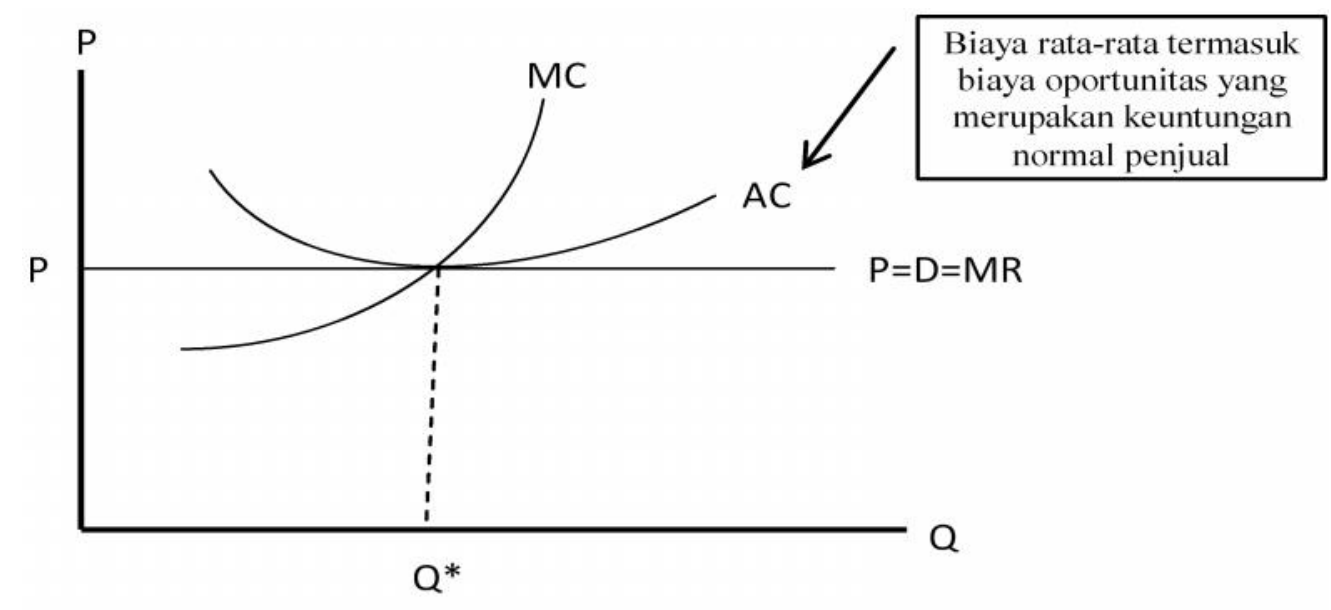

Gambar 1

Pasar Persaingan Sempurna dan Keuntungan Normal Penjual

2. Faktor yang mempengaruhi Keberhasilan dalam Persaingan

Berbagai usaha harus dilakukan oleh penjual menghadapi ketatnya persaingan. Salah satunya adalah membentuk model manajemen Islam sebagaimana yang dikemukakan oleh Abbasi, Rehman dan Bibi (2010). Terdiri atas pendekatan holistik dan etika bisnis Islam, model manajemen Islam bermanfaat menghadapi persaingan dan globalisasi.

Kazemian, dan Bahram (2011) telah mengkaji bagian dari model manajemen Islam yang berupa etika bisnis Islami. Etika bisnis Islami dikaitkan dengan kewirausahaan organisasional pengusaha. Mereka menyimpulkan bahwa ada korelasi antara etika bisnis Islami dengan kewirausahaan organisasional.

Faktor yang mempengaruhi keberhasilan dalam persaingan tidak hanya faktor sumber daya manusia, khususnya pendekatan holistik dan etika bisnis Islam. Masih banyak faktor lain yang mempengaruhinya. Jika menggunakan pendekatan bauran pemasaran, faktor sumber daya manusia masuk dalam kategori 'Person' di mana masih banyak kategori lain yang mempengrahui keberhasilan persaingan.
Hassan, Chachi dan Latiff (2010) mengemukan bahwa bauran pemasaran yang Islami terdiri atas lima ' $\mathrm{P}$ '. Bauran pemasaran yang Islami terdiri atas Person/ personality (SDM/Kepribadian), Price (harga), Product (produk), Place (Tempat dan bukti fisik) dan Promotion (promosi). Kesuksesan dalam peraingan ditentukan oleh penjual dalam mengelola lima ' $\mathrm{P}$ ' ini.

Jika mengasumsikan asumsi bahwa Person/personality, Price, Product sesuai standar, maka faktor Place dan Promotion menjadi faktor dominan dalam persaingan. Bahkan Place dan Promotion dapat disinergikan untuk meraih interest pelanggan. Place menjadi dasar bagi Promotion, dan Promotion memiliki nilai jual tinggi dengan mengungkapkan Place.

Desain ruangan kios yang nyaman, menarik dan informatif adalah realitas sinergi Place dan Promotion. Desain ruangan kios menjadi Place dalam arti bukan sekadar tempat penyimpanan barang, namun menjadi bagian dari bauran pemasaran. Demikian juga, desain ruangan kios menjadi Promotion dalam arti desain kios menjadi daya tarik bagi interest konsumen. Desain kios yang nyaman, menarik dan informatif menjadi pusat keunggulan dalam bersaing dengan penjual lainnya. 
Tujuan Pengabdian kepada kios Ar Ridho ini adalah

1. Mewujudkan kesamaan persepsi di antara stakeholder kios Ar Ridho bagi sketsa kios yang nyaman, menarik dan informatif

2. Mewujudkan sketsa kios Ar Ridho yang nyaman, menarik dan informative

3. Mengetahui persepsi konsumen terhdap sketsa desain kios Ar Ridho yang nyaman, menarik dan informatif

Manfaat dari pengabdian ini adalah mengimplementasikan ilmu ekonomi Islam dalam hal pasar, persaingan, dan etika pada pembuatan sketsa desain ruang kios Ar Ridlo di Pasar Klewer Surakarta. Selain itu, manfaat dari penelitian ini adalah mendukung perkembangan usaha kios Ar Ridlo. Adanya sketsa, diharapkan mendorong terwujudnya desain kios yang mampu meningkatkan omzet, meraih pasar kelas menengah dan melakukan ekspor. Demikian juga, pengabdian ini bermanfaat untuk mendukung kebijakan Direktorat Penelitian dan Pengabdian Masyarakat (2013) yang mensyaratkan pencapaian kemandirian ekonomi pada setiap kegiatan pengabdian masyarakat.

\section{METODE PELAKSANAAN}

Metode pengabdian yang digunakan adalah metode pendampingan. Kios Ar Ridho didukung dan dibantu dalam membuat sketsa desain kios. Dukungan diberikan dalam bentuk konsultasi menghadapi persaingan yang kompetitif dan memperoleh interest konsumen. Bantuan diberikan dalam bentuk partisipasi aktif dalam pengabdian masyarakat dan menentukan berbagai sektsa desain kios. Metode ini diharapkan menyebabkan pengabdian berjalan sesuai harapan.

Pendekatan stakeholder dan pendekatan kontingensi diterapkan pada pengabdian dan pendampingan untuk kios Ar Ridho. Pendekatan stakeholder menempatkan pengabdi sebagai bagian dari kios Ar Ridho yang harus berperan dan perannya dapat diterima oleh kios. Pendekatan stakeholder diharapkan menyebabkan pengabdian dilakukan secara efektif. Pendekatan kontingensi diharapkan menghasilkan lebih dari satu sketsa desain kios sehingga berbagai sketsa tersebut seolah-olah merupakan perwakilan konsumen.

Pendekatan stakeholder dan kontingensi yang dikemukakan oleh Abbasi dkk (2010) merupakan bagian dari pendekatan holistik dalam model manajemen Islam. pendekatan ini pernah diuji dalam kaitannya dengan model revitalisasi pasar Klewer (Universitas Muhammadiyah Surakarta, 2013). Pendekatan holistik mampu menyelesaikan konflik dalam revitalisasi pasar Klewer.

Pengabdian masyarakat ini dilakukan dalam empat tahap kegiatan. Tahap pertama adalah penyamaan persepsi tentang persaingan yang kompetitif dan pendekatan holistik. Penyamaan perspeksi ini diharapkan menimbulkan saling membutuhkan dan keinginan kuat interaksi antara pengabdi dan kios Ar Ridho dalam menghasilkan sketsa desain kios. Tahap pertama dilakukan dalam bentuk diskusi antara pengabdi dengan kios Ar Ridho pada akhir bulan Februari dan awal bulan Maret 2014. Tahap kedua adalah pendalaman permasalahan dihadapi kios Ar Ridho. Tahapan ini bermanfaat untuk memastikan bahwa persoalan utama yang dihadapi adalah desain rungan kios. Tahap kedua dilakukan pada pertengahan hingga akhir bulan Maret 2014. Tahap ketiga adalah pembuatan berbagai sketsa desain ruangan kios yang memenuhi kriteria nyaman, menarik dan informatif. Tahapan ini menggambarkan aplikasi pendekatan kontingensi. Tahap ini dilakukan pada bulan April 2014. Tahapan keempat adalah peninjauan oleh pelanggan terhadap berbagai sketsa desain ruangan kios. 
Tahapan ini dilakukan pada awal bulan Mei 2014.

\section{HASIL DAN PEMBAHASAN}

\section{Kesamaan Persepsi}

Diskusi menghasilkan kesamaan persepsi antara pengabdi dengan kios $\mathrm{Ar}$ Ridho. Karakteristik pasar Klewer yang memiliki banyak penjual dan pembeli menunjukkan bahwa persaingan harga tidak memberikan pengaruh. Persaingan harus dilakukan dalam bentuk persaingan nonharga. Interest konsumen yang beragam dapat diraih melalui perbaikan desain ruangan kios menjadi nyaman, menarik dan informatif. Bahkan perbaikan desain ruangan kios seperti itu menyebabkan kios ArRidho menjadi pionir dalam persaingan desain di pasar Klewer. Pionir dalam persaingan memiliki 'advantages' tersendiri dibandingkan yang bukan pionir dan yang sekadar mengikuti dalam persaingan. Salah satunya adalah pionir dalam desain ruangan yang Islami sesuai dengan bauran pemasaran yang sesuai dengan ajaran Islam.

Pendekatan stakeholder sangat penting, namun harus dipahami sebagai partisipasi aktif dalam pengabdian terhadap kios Ar Ridho. Pendekatan stakeholder bukan berarti penanaman saham atau modal pada kios Ar Ridho. Pendekatan stakeholder juga bukan ketergantungan kios Ar Ridho kepada pelaku pengabdian.

\section{Pendalaman Persoalan Kios Ar Ridlo}

Kios Ar Ridho ada di Pasar Klewer Surakarta. Lokasinya di bagian Barat pasar Klewer. Jalan menuju kios Ar Ridho paling cepat adalah melalui pintu utara Pasar Klewer. Papan nama kios Ar Ridho menjadi petunjuk bagi konsumen yang ingin membeli baju di kios tersebut. Gambar 2 menunjukkan papan nama kios Ar Ridho.

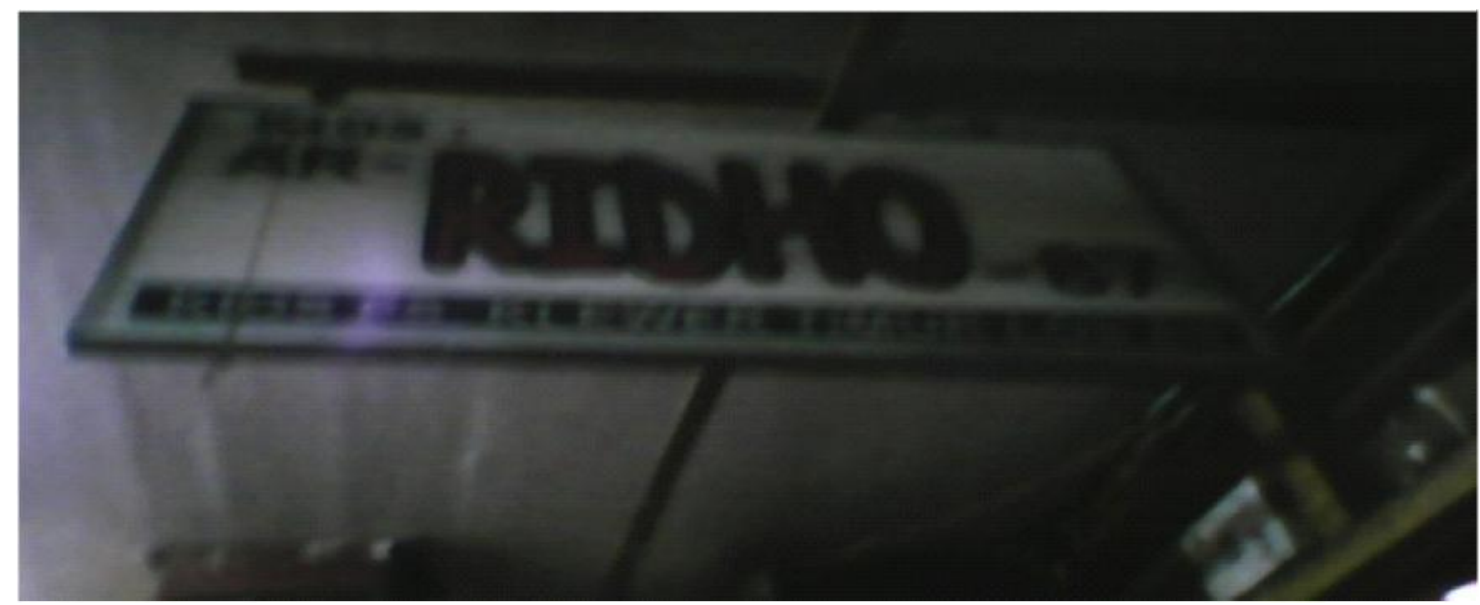

Gambar 2

Papan Nama Kios Ar Ridho di Pasar Klewer

Persoalan yang terjadi pada kios Ar Ridho adalah tidak ada desain ruangan kios yang menjadi patokan dalam penataan ruangan kios. Kios lebih mirip tempat penyimpanan barang. Akibatnya, konsumen merasakan bahwa desain kios tidak nyaman, tidak menarik dan tidak informatif. Gambar 3 menunjukkan bahwa kios Ar Ridho terdesain lebih sebagai tempat penyimpanan barang daripada tempat pertemuan dengan konsumen yang nyaman, menarik dan informatif. 
Gambar 3

Kios Ar Ridho di Pasar Klewer Terdesain

Sebagai Tempat Penyimpanan Barang

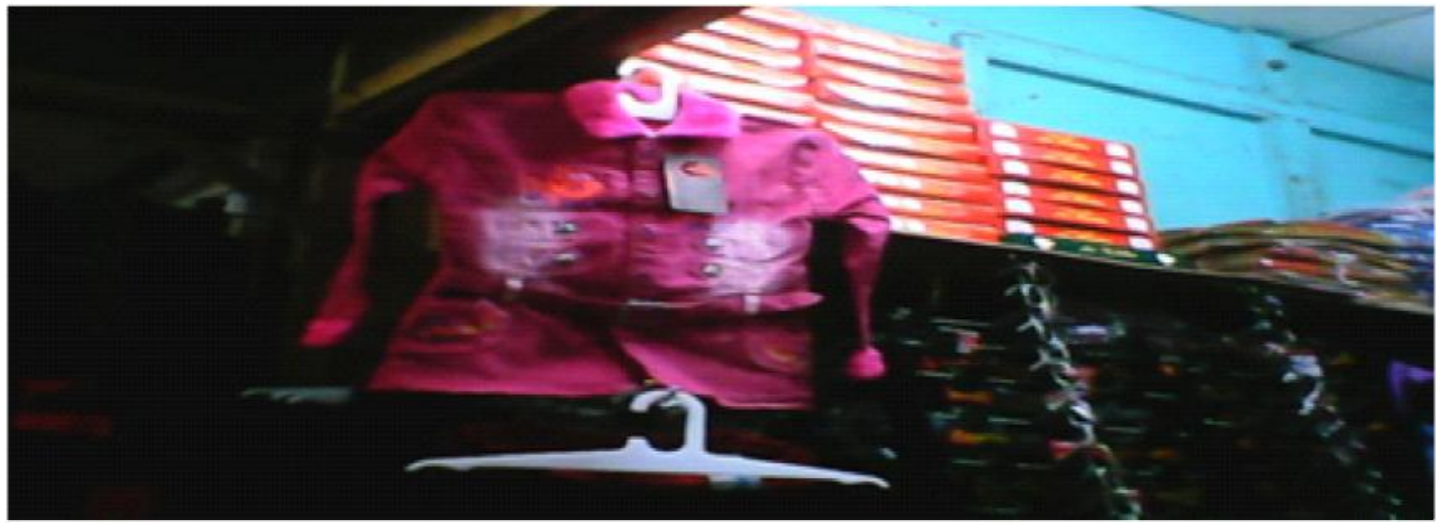

Gambar 4 menunjukan sisi kiri kios Ar Ridho. Ternyata, sisi kiri juga terdesain sebagai tempat penyimpanan barang. Dapat diduga bahwa yang yang tidak nyaman dan tidak tertarik degan kios Ar Ridho bukan hanya konsumen, namun juga pihak lain, termasuk pekerjanya. Perlu penataan kios Ar Ridho dari tempat penyimpanan barang menjadi tempat pertemuan dengan konsumen yang nyaman, menarik dan informatif.

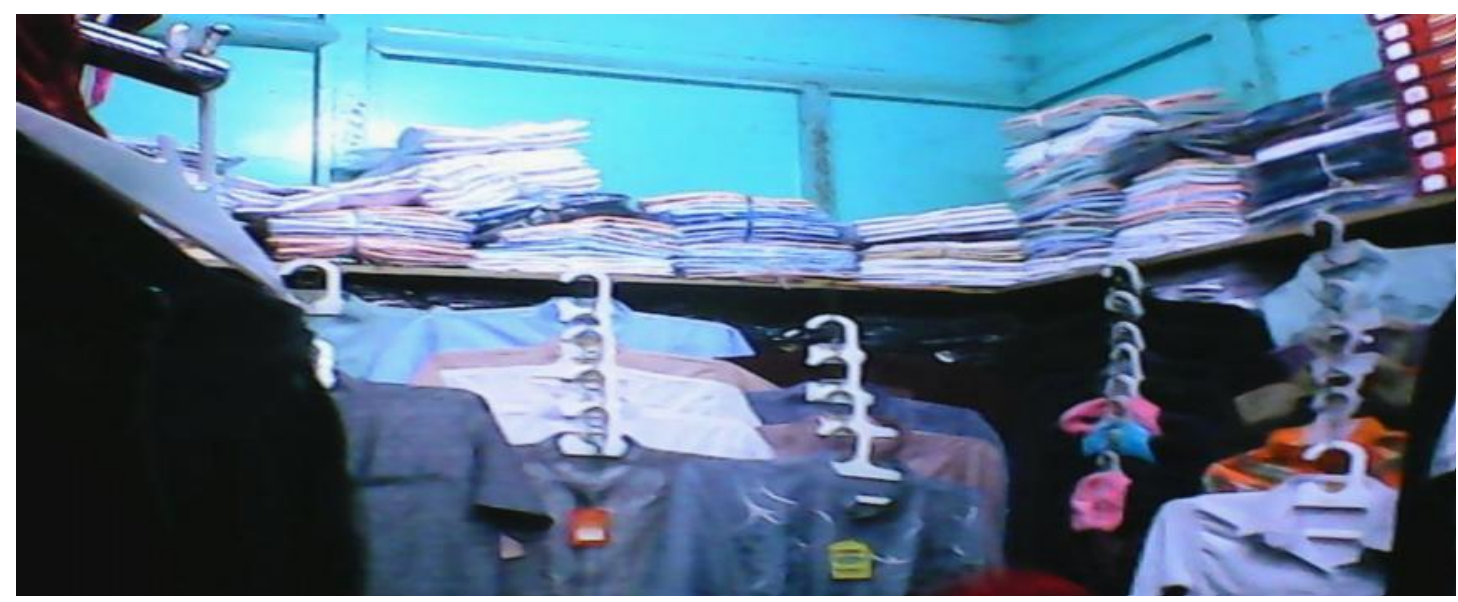

Gambar 4

Sisi Kiri Kios Ar Ridho di Pasar Klewer Juga Terdesain

Sebagai Tempat Penyimpanan Barang

Persoalan kios terdesain sebagai tempat penyimpanan barang bukan hanya persoalan kios Ar Ridho. Banyak dijumpai kios di Pasar Klewer yang memiliki persoalan seperti itu. Gambar5 menunjukan salah satu bagian kios di Pasar Klewer yang memiliki persoalan kios sebagai tempat penyimpanan barang. 


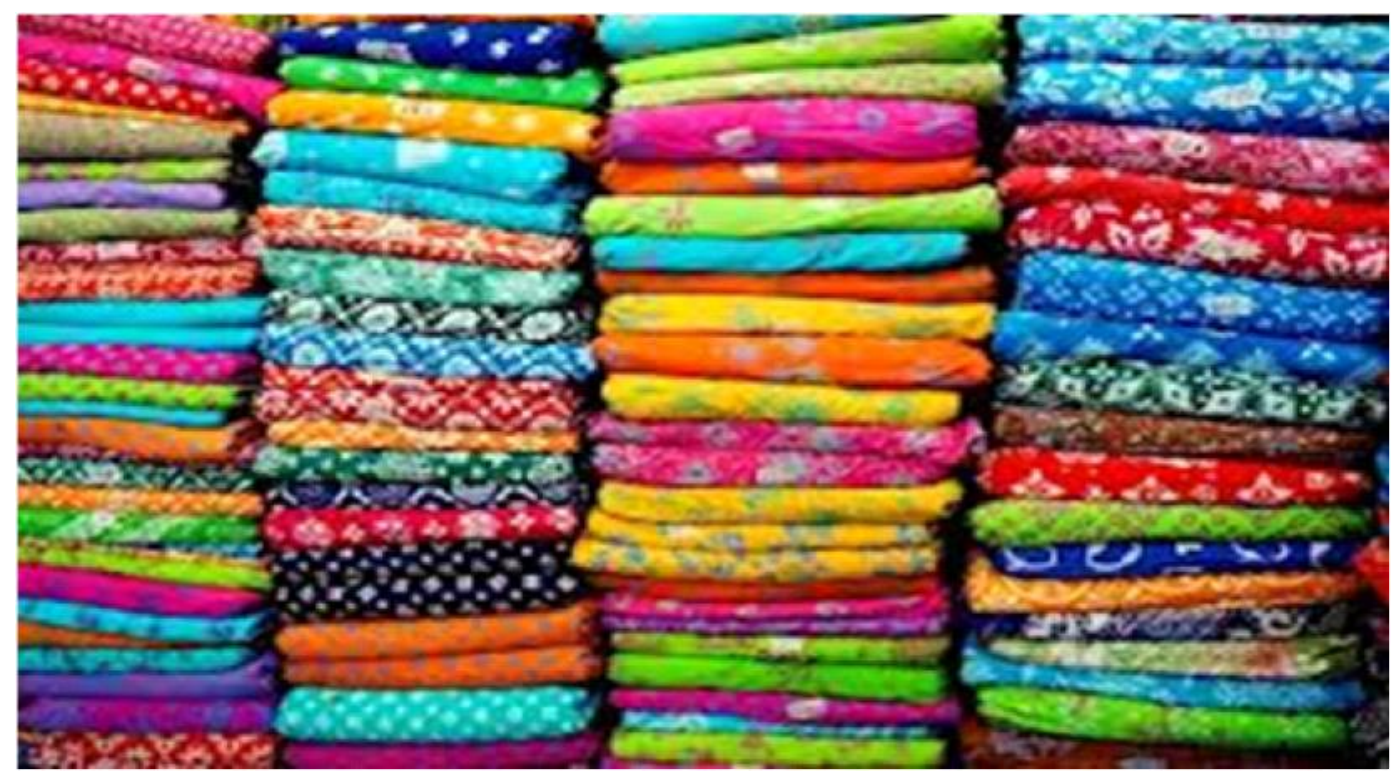

GAMBAR 5

Salah Satu Sisi Kios di Pasar Klewer juga Terdesain

Sebagai Tempat Penyimpanan Barang

Terdapat solusi lain bagi kios Ar Ridho, yaitu penjualan secara online. Hanya saja, solusi ini tidak dipilih sebab sebagaimana Gambar 6, diperkirakan sudah ada pihak lain di pasar Klewer yang melakukan penjualan online. Terdapat minimal dua 'kios' di Pasar Klewer yang sudah berjualan secara online. Setelah dicoba diakses, yang satu lebih sulit diakses dari yang lain. Jika kios Ar Ridho juga melakukan penjualan online, maka tidak menjadi pioner dan tidak mendapatkan 'advantages' darinya karena sudah ada yang melakukan. Hal ini berbeda dengan persaingan desain kios sebab belum ada yang melakukan. Pilihan bagi kios Ar Ridho adalah bersaing dalam desain ruangan daripada bersaing dalam penjualan online.

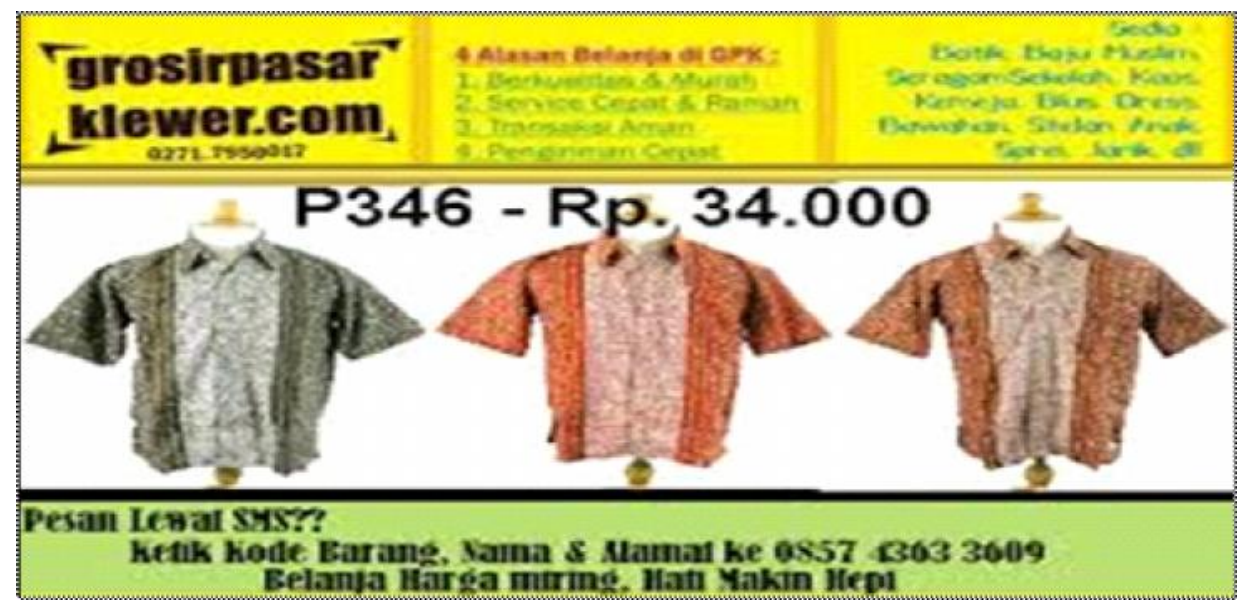

GAMBAR 6

Penjualan Online Sudah Dilakukan di Pasar Klewer

(a). www.grosirpasarklewer.com: tidak mudah diakses 


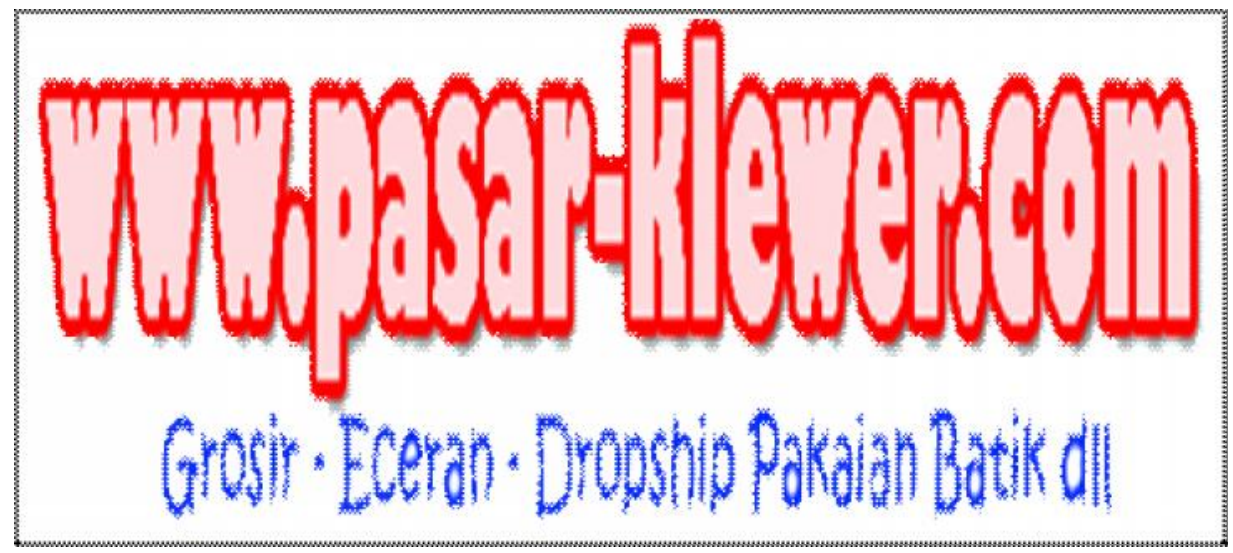

(b) www.pasar-klewer.com: mudah diakses

\section{Sketsa Desain Diperlukan}

Terdapat tiga sketsa desain untuk mengatasi persoalan yang dialami oleh kios Ar Ridho. Keseluruhan sketsa mengatasi persoalan kios Ar Ridho. Kios menjadi nyaman, menarik dan informatif. Hanya saja sketsa desain menunjukkan 'kekuatan' informasi yang berbeda-beda.
Gambar 7 menunjukkan sketsa desain kios Ar Ridho yang nyaman, menarik dan informatif. Sketsa kios yang nyaman dan menarik terdapat pada pemasangan kipas angin dan penataan display yang mencerminkan kelonggaran ruangan. Sketsa kios yang informatif terdapat pada peggunaan komputer informasi.

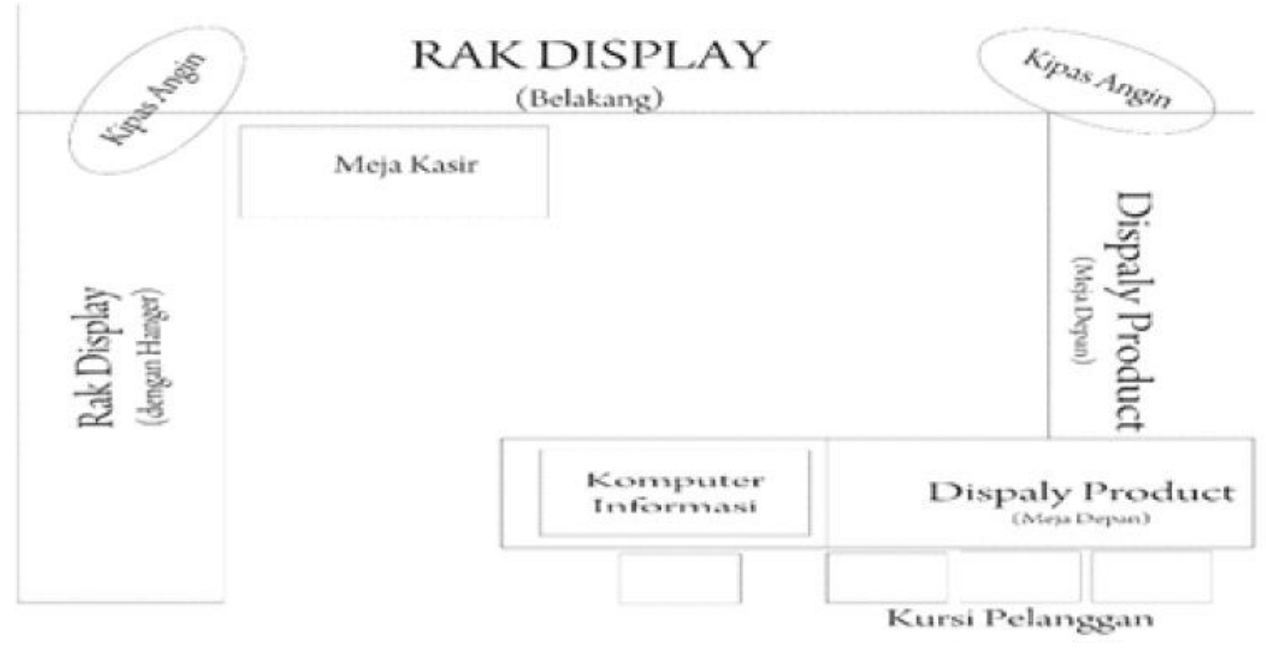

GAMBAR 7

Sketsa Desain Kios Nyaman, Menarik dan Informatif

Gambar 8 menunjukkan sketsa desain kios Ar Ridho yang mempertimbangkan aspek informasi produk dari sisi konsumen. Kios Ar Ridho dilengkapi dengan cermin besar. Cermin tersebut dapat digunakan sebagai alat bagi konsumen untuk mendapatkan informasi lebih nyata tentang produk yang diinginkan. 


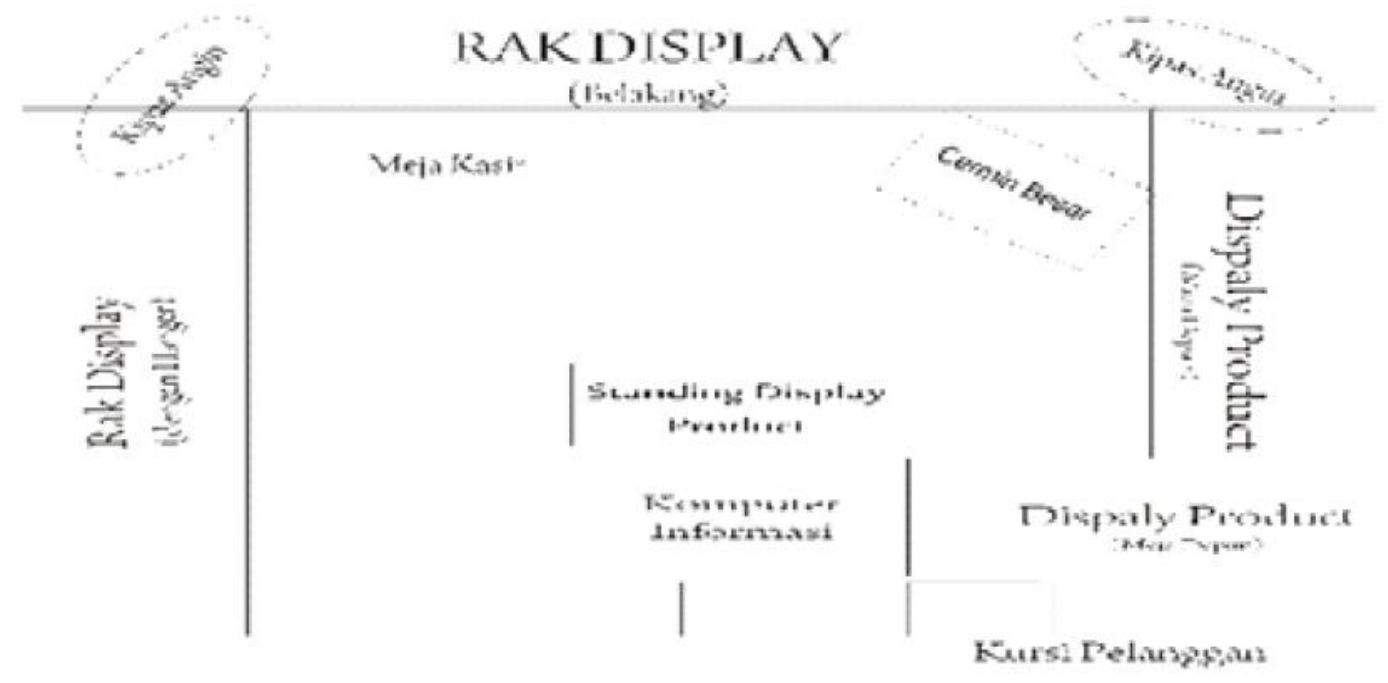

GAMBAR 8

Sketsa Desain Kios Nyaman, Menarik dan Lebih Informatif: Cermin Besar

Gambar 9 menunjukan sketsakios Ar kepastian produk sebelum pembelian. Ridho yang nyaman, menarik dan sangat Harapannya konsumen benar-benar informatif. Pada kios disediakan kamar pas mendapat informasi bahwa produk yang bagi konsumen yang ingin mendapatkan dibeli merupakan pilihan terbaik.

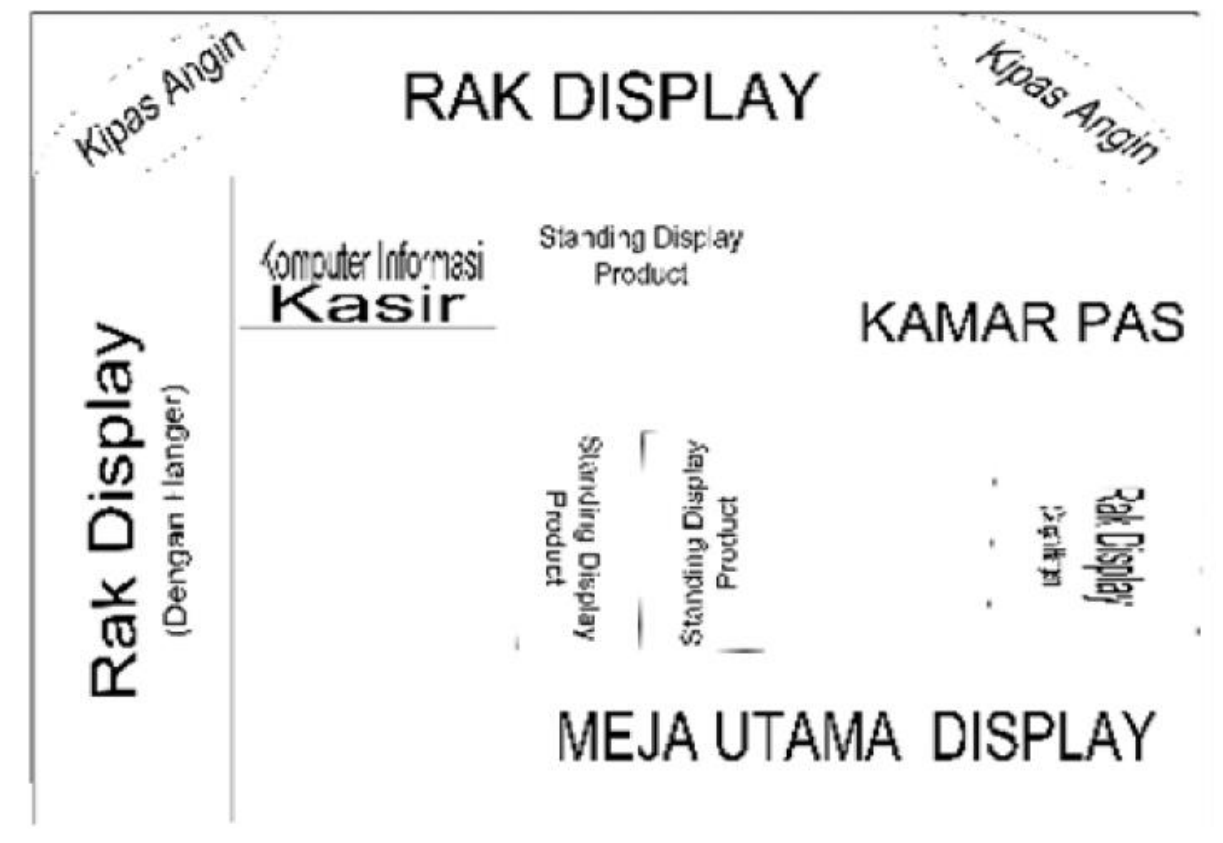

GAMBAR 9

Sketsa Desain Kios Nyaman, Menarik dan Sangat Informatif: Kamar Pas

Tinjauan Konsumen

Konsumen setuju dengan usaha untuk mengubah kios dari berpola tempat penyimpanan barang menjadi berpola tempat pertemuan dengan konsumen yang nyaman, menarik dan informatif. Konsumen juga 
setuju dengan sketsa desain, khususnya yang mendisplay kamar pas. Namun demikian beberapa kritik dan saran diberikan sebagai berikut:

1. Kios diperluas 2 kali atau 3 kali dari yang sekarang berukuran3X4 meter. Harapannya aspek kenyamanan betulbetul terpenuhi.

2. Display dipilah-pilah. Misal display baju dengan non baju.

3. Tempat penyimpanan barang tetap diperlukan. Sangat bagus jika kerja sama dengan kios lain dalam penyimpanan barang. Sebagai contoh kerja sama 5 kios display didukung 1 kios penyimpanan barang.

4. Sketsa desain dibuat 2 atau 3 dimensi.

5. Komputer informasi dikembangkan sebagai media transaksi online.

6. Sketsa dilengkapi dengan perkiraan biaya dibutuhkan dan perkiraan pendapatan diperoleh.

\section{KESIMPULAN}

Sketsa desain kios Ar Ridho menunjukkan bahwa kios Ar Ridho dapat melakukan salah satu bauran pemasaran yang sesuai agama Islam, melalui bentuk kios yang didesain nyaman, menarik dan informatif sesuai kehendak konsumen. Sketsa kios yang nyaman dan menarik berupa bagian tengah kios yang luas, sketsa kios yang informatif berupa adanya komputer informasi, cermin dan kamar pas. Sketsa tersebut menunjukkan bahwa kios Ar Ridho siap bersaing meraih beragam konsumen sehingga pendapatannya meningkat. Adapun pada masa yang akan datang siap bersaing untuk mendapatkan interest kosumen kelas atas dan melakukan ekspor.

Sketsa desain kios Ar Ridho yang nyaman, menarik dan informatif diperoleh melalui pendampingan berbasis pendekatan stakeholder dan kontingensi. Pendekatan stakeholder dalam pengabdi berpartisipasi aktif dalam pengabdian dan pendekatan kontingensi dalam arti tidak hanya ada 1 sketsa, namun ada 3 sketsa desain kios yang dihasilkan.

\section{PERSANTUNAN}

Penulis MEngucapkan terima kasih kepada Pimpinan Fakultas Ekonomi dan Bisnis Universitas Muhammadiyah Surakarta atas pembiayaan melalui skim Pengabdian Masyarakat Kolaboratif.

\section{DAFTAR PUSTAKA}

Abbasi, Abdus Sattar Kashif Ur Rehman dan Amna Bibi. 2010. "Islamic Management Model". African Journal of Business Management Vol. 4(9), 4 August, 2010. 1873 - 1882.

Direktorat Penelitian dan Pengabdian masyarakat. 2013. Panduan Pelaksanaan Penelitian dan Pengabdian Masyarakat Edisi IX.

Hassan, Abul, Abdelkader Chachi and Salma Abdul Latiff. 2010. "Islamic Marketing Ethics and Its Impact on Customer Satisfaction in the Islamic Banking Industry" JKAU: Islamic Economics, Vol. 21 No. 1. 27 - 46.

Kazemian, Ziba dan dan Bahram Ghamgosar. 2011. "The Relationship between Islamic Management and Organizational Entrepreneurship". Australian Journal of Basic and Applied Sciences, 5(10): 967-971.

Universitas Muhammadiyah Surakarta. 2013. Model Pengembangan Pasar Klewer Berdasarkan Prinsip Pasar Sehat Sebagai Perwujudan Kota Solo Sebagai Kota Budaya. Laporan Penelitian Institusional. 